\title{
Counter-Radicalization through Problem Based Learning in the Perspective of the Al Qur'an
}

\author{
Ahmad Zain Sarnoto', Nandang Burhanuddin ${ }^{2}$ \\ ${ }^{1}$ Pascasarjana, Institut PTIQ Jakarta, Indonesia \\ ${ }^{2}$ Direktur Insan Teladan Islamic Boarding School, Indonesia \\ 1ahmadzain@ptiq.ac.id \\ ${ }^{2}$ sekolah.it.insanteladan@gmail.com
}

doi) DOI: $10.37542 /$ iq.v4i01.195

\begin{abstract}
Abstrak
Kajian ini berangkat dari masalah meningkatnya kekerasan atas nama agama di dunia pendidikan khususnya sekolah dan pesantren. Pelakunya tidak hanya siswa, tetapi juga guru dan orang terdekat siswa. Infiltrasi tidak hanya dalam "misi agama" tatap muka (almujawwahah) tetapi telah menyusup ke buku teks dan kurikulum yang tersebar di seluruh negeri. Berbagai kajian dan pernyataan ahli yang menunjukkan kurikulum yang lemah, transfer ilmu yang kurang memadai di kalangan pendidik, ketidaktahuan, dan salah tafsir ayat-ayat alQur'an tentang radikalisme, terutama yang mengarah pada aksi terorisme dan sejenisnya di sekolah, adalah menjadi lebih kuat. Kelompok ISIS, Al-Qaeda, Jamaah Islamiyah, Laskar Jihad, MMI, Negara Islam Indonesia (NII), dan lain sebagainya menjadi perekrut utama mahasiswa di Indonesia. Sebagai konstruksi politik-agama, radikalisme adalah sebuah konsensus dan sengaja dibangun untuk menghancurkan tatanan dunia Islam dengan menyasar anak-anak rentan yang masih mencari jati diri. Oleh karena itu, diperlukan pendekatan pembelajaran yang komprehensif, sistematis, metodologis, dan analitis yang berbasis al-Qur'an dan Hadits oleh pendidik dan siswanya, melalui pembelajaran berbasis masalah. Pendekatan PBL merupakan pendekatan pendidikan untuk belajar dan sesuai dengan isi Alquran yang menekankan pada rahmatan lil'alamin, keadilan (adl), qawdah al hasanah, musyawarah, dan samahah. Meskipun para mufasir dan ulama memiliki pendapat yang berbeda mengenai konsep rahmatan lil 'alamin dan keadilan dalam pendidikan, pada umumnya bagi umat manusia pemikiran mereka sangat penting sebagai tonggak dan sumber ilmu, baik secara ontologis, epistimologis, maupun aksiologis baik secara muatan maupun aksiologis.
\end{abstract}


implementasi pembelajaran berbasis. problem (PBL) bagi upaya penanggulangan radikalisasi dalam dunia pendidikan di Indonesia, khususnya dunia.

Kata Kunci: Kontra-radikalisasi, pembelajaran, berbasis masalah, al-Qur'an

\begin{abstract}
This study departs from the problem of the increasing violence of movements in the name of religion in the world of education, especially schools and pesantren. The perpetrators were not only students but also teachers and those closest to the students. Infiltration is not only in faceto-face "mission religion" (al-mujawwahah) but has infiltrated textbooks and curriculum scattered throughout the country. Various studies and expert statements that indicate a weak curriculum, inadequate transfer of knowledge among educators, ignorance, and misinterpretation of the verses of the Al-Qur'an regarding radicalism, especially those that lead to acts of terrorism and the like in schools, are getting stronger. The ISIS groups, Al-Qaeda, Jamaah Islamiyah, Laskar Jihad, MMI, the Islamic State of Indonesia (NII), and so on have become the main recruiters of students in Indonesia. As a religio-political construction, radicalism is a consensus and is built deliberately to destroy the Islamic world order, targeting vulnerable children who are still looking for self-identity. Therefore, a comprehensive, systematic, methodological, and analytical approach to learning based on Al-Qur'an and hadith is needed by educators and their students, through problem-based learning. The PBL approach is an educational approach to learning and is in accordance with the content of the Qur'an which emphasizes rahmatan lil'alamin, justice (adl), qawdah al hasanah, deliberation, and samahah. Although, the mufasirs and scholars have different opinions regarding the concept of rahmatan lil 'alamin and justice in education, generally for mankind, their thoughts are very significant as a milestone and source of knowledge, both ontologically, epistemologically, and axiologically for the content and implementation of based learning. problem (PBL) for efforts to counter radicalization in the world of education in Indonesia, especially the world.
\end{abstract}

Keywords: Counter-radicalization, learning, problem based, al-Qur'an

\title{
Introduction
}

Cases of religious-based violence committed by school children were identified as 102 with the predicate "radicalized perpetrators". But, there are also teachers and even the Principal of SMPN in West Kalimantan who indicated pro radicalism. In 2017, a teacher in Banten, suspected of being a funder of one of the pilgrim activities that has a close relationship with 
terrorism. ${ }^{1}$ Noor Huda Ismail, revealed that after the Bali Bombings, there were about 50 schools affiliated with Jemaah Islamiyah (JI) in Indonesia, infiltrating boarding schools with invisible recruitment and regeneration processes. ${ }^{2}$ The results of research from the Institute of Islamic Studies and Peace (LaKIP) Jakarta between October 2010 to 2011 against PAI teachers and students (junior high and high school) in Jabodetabek also showed that $49 \%$ of students agreed with the act of radicalism for the sake of religion. ${ }^{3}$ The data can not be blamed if Islamic educational institutions in Indonesia such as madrasas or boarding schools are considered as the basis of terrorist seed seedlings. ${ }^{4}$ Therefore, it is natural if there are allegations that education and educational institutions are very likely to be the spreaders of the seeds of radicalism although on the other hand it is also an antidote (read: counter-radicalization) radical Islam.

Studies on radicalism and terrorism have also insinuated that certain Islamic educational institutions, especially nonformal ones such as pesantren, have taught fundamentalism and radicalism to students. ${ }^{5}$ Azyumardi Azra who said that school children become special targets of recruitment of terrorist groups and radicalists such as ISIS. From the final level of junior high school to high school and students due to naivety or vulnerability of age; the indifference of teachers and lecturers to the penetration and infiltration of radical and terrorist outside groups, some even support radical movements. ${ }^{6}$ In the approach of instructional communication (learning) can be explained that the process of transmitting messages between teachers (communicators) and students (communicant) both conduct psychological interactions that can bring about the process of changing knowledge, attitudes, and skills on the part of communicant. ${ }^{7}$ And, if a teacher assumes terrorism as a common occurrence in a trajectory of life for his protégé, just as he is opening his students' doors to enter into the space of terror-spreading ideology.

In response to the terror and violence committed by religious individuals above, religious elites are divided into two main strongholds. First, religious defenders who seek to

\footnotetext{
1 https://www.tempo.co/abc/4505/radikalisme-berbalut-pendidikan-sudah- menyasar-anak-usiadini-di-indonesia

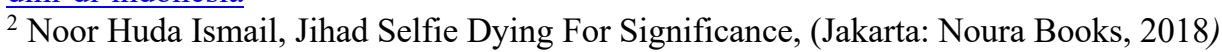

3 Abu Rokhmad, "Radikalisme Islam Dan Upaya Deradikalisasi Paham Radikal," dalam Jurnal Walisongo, (Mei 2012), Vol. 20, No. 1, 81.

${ }^{4}$ Andik Wahyun Muqoyyidin, "Membangun Kesadaran Inklusifmultikultural untuk Deradikalisasi Pendidikan Islam," dalam Jurnal Pendidikan Islam, (Desember 2012), Vol. I, No. 2, 133.

${ }^{5}$ https://www.google.co.id/?AzyumardiAzra.Rekrutmen/Anak/Sekolah. diakses tanggal 05-04-2017

${ }^{6}$ https://www.google.co.id/?AzyumardiAzra.Rekrutmen/Anak/Sekolah. diakses tanggal 05-04-2017

${ }^{7}$ Pawit Yusup, Komunikasi Instruksional (Bandung : Remaja Rosdakarya, 2010), 57
} 
distance religion from acts of violence and terrorism. They say that religion is not only neutral over violence, but also against it and therefore religion is an innocent victim of members of hardline groups. These people, they say, have hijacked a peace-loving religion. Second, secular academics and scholars and analysts who have always argued that political and economic factors are the cause of violent acts and social conflicts. ${ }^{8}$ Khâlid ibn Shâlih ibn Nahîdh AdzhZhariry stated that the curriculum, teaching materials, especially Islamic teaching materials, is very weak, not even able to meet the needs of students in the process of awareness around religious affairs, let's enlighten their thinking in the face of the problems of contemporary life today. The effect is fatal, namely the lack of religious awareness in general that has an impact on the negative effects in the behavior, attention, and behavior of members of the community. ${ }^{9}$

Sartono Kartodirdjo defines radicalism as "a social movement that completely rejects the ongoing social order and is characterized by strong moral aggravation to oppose and be hostile to the privileged and ruling people". ${ }^{10}$ Misconceptions and misinterpretations in the texts of the Al-Qur'an due to the narrow and naïve mindset of school students who are fed by adult radicalism actors are the root of acts of terrorism, such as the interpretation in surah Muhammad (47) verse 4, which orders the killing of kafir.11 According to Karen Armstrong's research, the phenomenon of religious fundamentalism-radicalism does not only belong to monotheistic religions. There are also Buddhist-Hindu fundamentalism and even Confucianism which both reject the points of liberal cultural values and fight each other in the name of religion and try to bring sacred things into political and state affairs. ${ }^{12}$

On 22 July 2011 there was a series of tragic events in Norway that killed around 90 people by the youth division of the Labor Party. The assassination of Israeli Prime Minister Yitzhak Rabin on November 4, 1995 by Yigal Amir, a young (student) Jewish extremist. ${ }^{13}$ The text of the Qur'an is indeed very open to interpretation (multi-interpretable) and every commentator when interpreting the Koran is usually also influenced by the socio-cultural

\footnotetext{
${ }^{8}$ Abdul Muis Naharong, "Terorisme Atas Nama Agama," Journal of Refleksi, (2013), Vol. 13, No. 596.

${ }^{9}$ Khâlid bin Shâlih bin Nahîdh Adzh-Zhariry, Daur At-Tarbiyyah fî Muwâjahat Al- Irhâb, (Saudi Arabia: Kementrian Pendidikan Tinggi Universitas Ummul Qura, 1421 H), 60-61. Juga makalah Asmâ binti Abdul Azîz; و النطرف دراسة نحلبلة أسباب الرئر هاب والعنف

${ }^{10}$ Lihat N. Alim, Pairin, dkk, Singularitas Agama: Identifikasi Aliran dan Paham Radikal di Kendari Al-Ulum, (2 December 2018), Volume 18 No. 2, 271-300

${ }^{11}$ Ahmad Rizky Mardhâtillâh 'Umar, “Melacak Akar Radikalisme Islam di Indonesia,” dalam Jurnal Ilmu Sosial dan Ilmu Politik, (November 2010), Vol. 14, No. 2, 171.

${ }^{12}$ Lihat Khoirul Mudawinun Nisa', Reinterpretasi Jihad Pdm \& Pcnu Kota Madiun Sebagai Upaya Membendung Laju Radikalisme, Jurnal Piwulang, (September 2018), Vol. I No.8, 33-53 Reinterpretasi Jihad Pdm \& Pcnu Kota Madiun Sebagai Upaya Membendung Laju Radikalisme Agama Khoirul Mudawinun Nisa'

${ }^{13}$ Abdul Muis Naharong, "Terorisme atas Nama Agama," dalam Jurnal: Refleksi, (Oktober 2013), Vol. 13, Nomor 5, 94.

4 | IQ (Ilmu Al-qur'an): Jurnal Pendidikan Islam| Volume 4 No.01 2021, 1-16
} 
conditions in which he lives, even the political situation that surrounds it is also very influential and there is a tendency within him. An interpreter to understand the Al-Qur'an in accordance with the discipline he is engaged in so that even though the object of study is single, namely the text of the Al-Qur'an, the results of the interpretation of the Qur'an are not singular, but plural. Wâsim Fathullah defines ikhtilâf (difference) in the interpretation of the Qur'an as "the disagreement of the Qur'anic reviewers in understanding the designation of a verse or lafazh of the Al-Qur'an in relation to its conformity with the will of Allah Swt. from that verse where the commentator then deduces a meaning that other commentators have not concluded. "14

This happens when it is done by ordinary people or groups who are still in the learning stage (students). They negate each other and on the other hand think that what he believes is the only truth (single truth). There are claims of truth that never fail to plunge them into clash, conflict, especially in understanding Islamic law in their world, especially in schools. This is a requirement of Laws No. 20 of 2003 concerning the National Education System in Article 3 which emphasizes the formation of national character. The meaning and intention above is of course very much dependent on the curriculum used, not only at the conceptual level, but also on how religious values appear in the building of a qualified national character.

Ellys Lestari Pambayun's research related to the context of the anti-State philosophy among students reports the fact that the Citizenship Education course on campus is less attractive to students, in addition to unattractive substances, the role of teachers who are less creative, innovative, and intelligent in packaging messages of nationality and Pancasila. ${ }^{15}$

Even in the rational section of the 2004 curriculum, it is stated that the weakness of the Islamic religious education curriculum is in terms of material that is more focused on cognitive enrichment and minimal in the formation of affective and psychomotor sides. Another obstacle is the lack of participation of teachers in other subjects in motivating students to practice the values of religious education in their daily lives. Likewise, the lack of teacher resources in developing more varied approaches and methods, the lack of various training and development facilities, and the low participation of parents. ${ }^{16}$

In addition, it is also found in the book "Pendidikan Agama Islam" (Islamic Religious Education) for Semester II to improve student competency standards to be able to read and

\footnotetext{
${ }^{14}$ Astuti, "Diskursus Tentang Pluralitas Penafsiran Al-Qur'an,” Jurnal Hermeunetik, (Juni 2014), Vol. 8, No. 1, 117.

15 Ellys Lestari Pambayun, Pendekatan Komunikasi Instruksional Pada Dosen Pendidikan Kewarganegaraan di Perguruan Tinggi, Jurnal Ilmu dan Budaya, (2013), Vol. 37 No. 32.3214

${ }^{16}$ Depdiknas, Kurikulum 2004; Mata Pelajaran Pendidikan Agama Islam Sekolah Menengah Atas Dan Madrasah Aliyah, (Jakarta: Depdiknas, 2003), 7.
} 
interpret Ali Imrân verse 159, Surat Al-Mâidah [5] verse 51, and Asy-Syûrâ verse 38, in order to display life behavior. Democratic in accordance with the contents of these two verses. Specifically, looking at the last point that "it is not permissible to have deliberation to elect a leader for Muslims who are not Muslims" from the content of verse 51 of Surah Al-Mâidah [5] which translates as: "O you who believe, do not make people. Jews and Christians are loyal friends (mu), they protect each other. Whoever among you makes them loyal friends, then in fact he is one of them. " The translation issued by the Ministry of Religion looks a little different from the description in this textbook. ${ }^{17}$

\section{Research Method}

This study uses a qualitative approach in order to interpret the reality and behavior of people in natural settings. ${ }^{18}$ While the study method is a combination of literature studies on references that correlate with the theme of deradicalization in the world of education as well as interviews conducted to obtain empirical data on parties related to the study theme, such as schools (teachers and students, both in Jakarta and Bandung), scholars, and education activists.

\section{Result and Discussion}

This study will discuss problem-based learning approaches (problem-based learning / PBL) which are integrated in the Al-Qur'an in reducing radical understanding in the world of education. From the data obtained, Islamic education has so far colored violence in the name of religion that is structured by one or several organizations with radical Islamic ideologies, such as ISIS and Al Qaeda which flourish in Indonesia. Akbar S Ahmed, an Islamic postmodernist figure also emphasized that Islamic education is facing a problem. Islamic education is too narrow and encourages religious chauvinism. ${ }^{19}$

Kauffman explains why children are vulnerable targets for a radical injection of understanding, because they have prominent emotional and behavioral problems. Likewise, Loeber emphasized that children are developing with one of the characteristics, namely various

\footnotetext{
${ }^{17}$ Abu Rokhmad, "Paham Radikal Islam Dan Upaya Deradikalisasi Paham Radikal," 90.

${ }^{18}$ Ellys Lestari Pambayun, One Stop Qualitative Reserach Methodology in Communication, (Jakarta: Lentera Cendekia, 2013).

${ }^{19}$ Akbar S. Ahmed, Islam sebagai Tertuduh, (Bandung : Arasy Mizan, 2004), .244

6 | IQ (Ilmu Al-qur'an): Jurnal Pendidikan Islam| Volume 4 No.01 2021, 1-16
} 
types of aggression which tend to lead to violence. ${ }^{20}$ Likewise, Loeber emphasized that children are developing with one of the characteristics, namely various aggressiveness that tends to lead to violence. ${ }^{21}$

Therefore, methods, perspectives, and concepts of counter-radicalization in schools to fortify the invasion of foreign ideas that threaten their lives individually and in groups are needed. The problem-based learning approach (Problem Base Learning) with the Al-Qu'ran perspective as two integrated and interconnected perspectives can be an alternative source of knowledge and essential behavior of students and teachers in schools because it has a counterradicalism configuration in instilling a kaffah Islamic mindset. And current, which can be explained as follows:

Radicalism is a form of action that deviates from sharia. Ibn Fâris ra in his "Mu'jam Maqâyis Lughah" defines radical as violence and rigidity, something that is exaggerated and transcends boundaries and standards. The concepts of the Al-Qur'an which are humanist, tolerant, pro-justice, love others, and other noble content, can be described as follows:

\section{The Concept of Maqâshid Syari'ah}

Imam Suatiby explained that whatever the reason, according to the Al-Qur'an, radicalism in educational institutions or by school children with the various results of the thinking of the schools in them is not in line with bringing the children of this nation as human beings towards their lives that are problematic and just for life. the world and the hereafter. ${ }^{22}$

PBL follows the method of the Al-Qur'an and offers thought in dividing maqâshid into three basic classifications. First, which is dharûriyât (primary). Maqâshid which is dharûriyât is something that is obligatory and becomes the main and is the foundation of the existence of school children as human beings who must exist for the benefit of humans. ${ }^{23}$ Like, fitrah, according to the word of Allah Surah Ar-Rûm [30] verse 30 and tolerance (samâhah) or moderate, egalitarian, not rigid in the process of mu'âmalah in Surah Shâd [38] verse 26, AnNisâ [4] verse 171, and Al-Hadîd [57] verse 27.

${ }^{20}$ F.J. Monks, AMP Knoers, \& Siti Rahayu Hadinoto, Psikologi Perkembangan, Pengantar dalam Berbagai Bagiannya, (Yogyakarta : University Gadjah Mada Press, 2006), 369

${ }^{21}$ F.J. Monks, AMP Knoers, \& Siti Rahayu Hadinoto, Psikologi Perkembangan, Pengantar dalam Berbagai Bagiannya, 373

${ }^{22}$ Syaikh Muhammad Thâhir bin 'Âsyûr, Maqâshid Asy-Syarî’ah, (Jordania: IIIT, 1999,), Cet I, 189.

${ }^{23}$ Syaikh Muhammad Thâhir bin 'Âsyûr, Maqâshid Asy-Syarî'ah, 200. 
Second, those that are hâjiyât (secondary) are things that are needed by humans, especially school children with the aim of making it light, airy, comfortable in overcoming the difficulties that must be endured in navigating through life according to the word of Allah SWT in Surah Al-Baqarah. 2] verses 286 and 185, A1-Hajj [22] verse 78. Apart from that, the Prophet Muhammad saww said about the obligation to preach by making it easier and not difficult. ${ }^{24}$

Third, which is tahsiniyât (tertiary). This maqâshid tends to the things that are necessary to make life more beautiful and harmonious. The absence of these tertiary things does not bring chaos, as in the absence of the necessities of life (dharûriyât) or hâjiyât. Such as, virtues (virtues), good ways (good manner), and the improvement of ways of life. ${ }^{25}$ His proof is contained in Surah Al-Qalam [68] verse 4.

\section{The Concept of Rahmatan lil'Âlamîn}

Humanist problem-based learning (PBL) as well as the curriculum is in accordance with the concept of رحمة (rahmah) and its derivation is found in the Al-Qur'an with the mention of 199 times, in the hadith it is mentioned 57 times and in the atsar it is recorded 8 times. Rahmatan lil alamîn is found in Surah Al-Anbiyâ [21] verse 107. The commentators have different opinions when interpreting the word rahmatan lil 'alamîn above. Imâm Abû Ja'far Ath-Thabarî said, "The commentators have different opinions on this issue, whether rahmatan lil 'alamîn is specifically intended for Muslims or generally applies to all humans." The opinion that is more accurate in this matter is the words narrated by Ibn 'Abbas, he said that Allah sent the Messenger of Allah as a mercy for all nature, be it believers or those who disbelieve. To those who believe, Allah gives guidance, and for the disbelievers, Allah postpones torment for them as happened to the previous Ummah. ${ }^{26 " ~ I m a ̂ m ~ A l-Q u r t h u ̂ b i ~ a n d ~ I b n ~ K a t h i r ~ a l s o ~ a g r e e ~}$ with this opinion. ${ }^{27}$

PBL education is actualized in the context of Islam as rahmatan lil 'alamîn, strengthened by - at least - four basic principles, representing many sides of life. The four

\footnotetext{
${ }^{24}$ Yûsuf Ahmad, Maqâshid Asy-Syarî'ah 'Inda Imâm Ibn Taymiyyah, (Jordania: Dâr An-Nafâis, 2000), 66.

${ }^{25}$ Yûsuf Ahmad, Maqâshid Asy-Syarî’ah 'Inda Imâm Ibn Taymiyyah, 66.

${ }^{26}$ Imâm Ath-Thabari, Jami' Al-Bayân fî Ta'wîl Al-Quran, (Kairo: Hajar Li Ath- Thabâ'ah wa An-Nasyr wa AtTauzi' wa Al-I'lân, tt), Cet. 2, Vol. 18/552.

${ }^{27}$ Shâlih Shoubâni dkk, Qiyam At-Tasâmuh fii Al-Manâhij Al-Madrasiyyah Al- 'Arabiyyah, (SA: Ramallah Centre for Human Rights Studies, 2012), 13.

8 | IQ (Ilmu Al-qur'an): Jumal Pendidikan Islam| Volume 4 No.01 2021, 1-16
} 
principles are; 1. At-tasâmuh (tolerance); 2). At-tawassuth (moderatism); 3). At-taisîr (makes it easy); 4). At-tabsyîr (to cheer up). ${ }^{28}$

In Islam, humanistic education (rahmatan lil 'alamin) is meant to humanize humans according to their role as caliph on earth. One of the studies on "Islamic Humanistic Education through Applicative Learning" (Study at the Darunnajah Ulujami Islamic Boarding School, Jakarta) is a form of modern Islamic boarding school (kholaf) which strengthens the basic humanistic principles of education. Learning in this boarding school is carried out in classical form (class). Darunnajah Islamic boarding school does not provide learning of the yellow book, so it does not recognize the bandongan, wetonan and sorogan methods. To improve the quality of educational outcomes, it can be done through habituation which is implied in the applied learning model. Applicative learning is carried out in almost all subjects, especially language subjects, both Arabic and English. The good quality of the outcome of the Darunnajah Islamic Boarding School is seen through the quality of its alumni who are widely accepted both in several fields of work (profession) and in the community. ${ }^{29}$

\section{Qudwah Hasanah (Good Example)}

In PBL, the teacher is a central figure or good role model (qudwah hasanah) that their children will emulate. He as a voice of kindness (mauizati hasanati) is also a preacher for his children to always walk and return to the teachings of the Al-Qur'an and hadith. ${ }^{30}$

A study on the importance of the teacher's role as qudwah hasanah produced by M. Nur Ghufron and Rini Risnawita S which explains that the interaction process (teacher-student) is very important, because during this interaction process there is cognitive apprenticeship. namely the process in which a person who is learning step by step gains expertise through his interactions with people around him who have a better understanding of religiosity. ${ }^{31}$

\section{Ash-Syûrâ (Deliberation)}

\footnotetext{
28 Shâlih Shoubâni dkk, Qiyam At-Tasâmuh fii Al-Manâhij Al-Madrasiyyah Al- 'Arabiyyah, (SA: Ramallah Centre for Human Rights Studies, 2012), 13.

29 Nurbaiti, "Pendidikan Humanistik Islami melalui Pembelajaran Aplikatif (Studi di Pondok Pesantren Darunnajah Ulujami, Jakarta”, Jurnal KORDINAT, (April 2019), Vol.XVIII No, 172

3030 Asmâ' binti Râsyid Ar-Ruwasyid, Al-Qudwah, (Dâr Al-Wathan Li An-Nasyr, 2010), 13-15

${ }^{31}$ M. Nur Ghufron dan Rini Risnawita, "Teori Vygotsky dan Implikasinya dalam Pendidikan Agama Islam pada Anak", Jurnal Elementary, (Juli- Desember 2013), Vol.1 No.1, .75
} 
Problem-based learning (PBL) requires and facilitates that teachers, students, and parents as Islamic communities can be accommodative and compromise in applying the concept of state politics, namely democracy. As a country based on democracy, Indonesia applies modern governance based on Islamic principles, such as equality (al-musawa), freedom (al-hurriyat) and justice (al-'adl) which are in line with the normative foundation of Islamic teachings. 32

Al-Quran mentions the derivation of the word syûrâ in three verses, namely: Surat AlBaqarah [2]: 233; Surat Ali Imrân [3]: 159; and Surah Asy-Syûrâ [42]: 38.112. All three involve several aspects of human life, including aspects of family education, community and state administration. ${ }^{33}$

\section{Al-'Adâlah (Justice)}

In problem-based learning (PBL) the principles of just teaching (al-'adâlah) become a problem solving in its place. ${ }^{34}$ The foundation of his perspective in the word of Allah Swt which means: "And Allah does not love the zhâlim people." "And We prepare for those zhâlim a painful torment." Among the implications of PBL in the principle of justice for school students with teachers and society are: Legal justice, socio-economic justice, justice in relations between groups.

Thus, the PBL approach with the concept of deliberation based on al-musawa, alhurriyat, and al-'adl in the context of problem-based learning for students in schools as expressed by Winkel is a set of actions designed to support student learning, taking into account events. Extreme events that play a role in a series of internal events that take place experienced by students at school and outside of school.

\section{Problem-based Education Approach to Counter Radicalization}

This study describes a problem-based educational approach to counter-radicalization in the perspective of the Qur'an which finds several explanations, namely:

\footnotetext{
${ }^{32}$ Ahmad Tafsîr, Ilmu Pendidikan dalam Perspektif Islam, (Bandung: PT. Remaja Rosda Karya, 2010), Cet. 9, 143.

${ }^{33}$ M. Quraish Shihab, Wawasan Al-Qur"an: Tafsir Maudhû"i atas Pelbagai Persoalan Umat, (Bandung: Mizan, 1996), 471.

${ }^{34}$ Ahmad Syafii Maarif, Mencari Autentisitas di Tengah Kegalauan, (Jakarta, PSAP, 2004), 173.

10 | IQ (Imu Al-qur'an): Jurnal Pendidikan Islam| Volume 4 No.01 2021, 1-16
} 
Ontologically, it is found a reality that the emergence of radicalism in the world of education is due to misunderstandings and misinterpretations in the Qur'anic texts because the narrow and naive mindset of school students who are fed by adult radicalism actors is the root of acts of terrorism, such as the interpretation in surah Muhammmad. (47) paragraph 4, which orders the killing of unbelievers. Furthermore, the war orders until there is no slander on the earth in surah Al-Baqarah (2) verses 193 and 216, the order to fight against unbelievers in Surah At-Taubah (9) verses 29 and 41, surah Al-Mâidah (5) verse 44, Ali 'Imrân (3) verse 104, and so on. This reality is also not in line with the mission of education to foster a school environment according to the demands of Law No. 20 of 2003 concerning the National Education System in Article 3 which emphasizes the formation of the character of the nation (character buiding). Clearly, a problem-based learning approach that is integrated with the Koran can be an alternative to the Islamic education curriculum which is enforced not only at a conceptual level, but also includes the internalization of curricula on religious values that are counter-radicalized to creating development, capable national character. And, indeed, the crucial point in this writing is the weakness of the Islamic religious education curriculum, especially on cognitive, affective, and psychomotor enrichment materials. Apart from the lack of active participation of teachers of other subjects in motivating students to practice the values of religious education in their daily life. Likewise, the lack of teacher resources in developing more varied approaches and methods, the lack of various training and development facilities, and the low participation of parents.

Epistemologically, it was found that the general characteristics and nature of radicalism knowledge were obtained and considered groundless truth claims from students and teachers in schools who were involved in the movement because of the hegemonic play of Western power which actually thickened as acute fanaticism against Islam. The problem-based learning approach (PBL) with this instrument and learning framework aims to provide understanding to students starting from the history of the ISIS movement, Al-Aqida, Jama'ah Islamiyah, Laskar Jihad, NII, MMI, and so on that infiltrate schools and Islamic boarding schools in Indonesia originate from the internal political turmoil of the elites with the loss of the nation's children. Meanwhile, systematic and organized radicalism is also understood to be carried out by actors or intellectuals who are highly educated. This is marked by the emergence of a radical theological movement until now.

Axiologically, through the problem-based learning approach (PBL) discusses the true goals, nature, benefits, and value of science about radicalism. The value of the usefulness of science which is not value-free (value laden) is based on the Qur'an, so that at certain stages, 
knowledge often has to be adapted to the cultural and moral values of a society, for constructive, not destructive efforts. Several values and radical beliefs (understandings) that can be identified in everyday life.

The implementation of PBL in the concept of counter-radicalism in the world of education indeed requires Islamic education institutions to be more oriented towards things that are transfer of knowledge and skills in developing the intellectualization process and lack of attention in the formation of qalbun salîm by trying to create a generation that has basthatan fi al-'ilmi wa al-jism ”, covered by Islamic spiritualization and moral discipline. In addition to continuous anti-radicalism campaign campaigns in schools starting from the level of the Education Office or the Ministry of Religion, to the level of educational organizers involving POSG, teachers, and all elements of education in schools to community groups who are active in cyberspace such as Google, Facebook, Tweeter, Instagram , WhatsApp, Line, BBM, Path, Youtube, to the general public. 


\section{Image 1.}

\section{Problem-Based LearningEnvironment, Set within Three Stages. ${ }^{35}$}

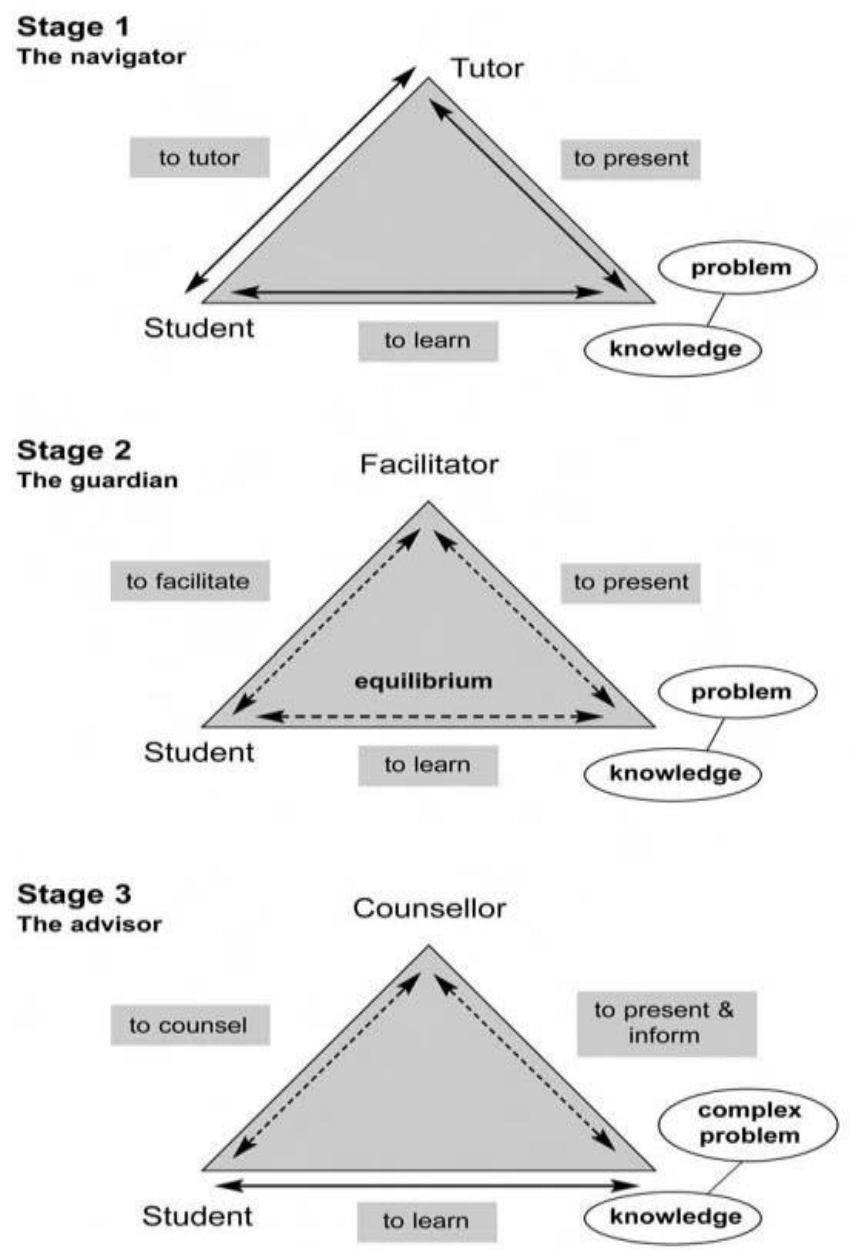

Comment: PBL involves the tutor (teacher) in a collaborative learning relationship with students. ${ }^{36}$ The facilitator needs to negotiate a new understanding of what radicalism is from the perspective of the Al-Qur'an in an interpersonal way in a small, open, discussive group. The counselor guides students to be able to provide input or conclusions about the existence of radicalism in their environment.

\footnotetext{
${ }^{35}$ Yves Mauffette, Peter Kandlbinder and Alexandre Soucisse, The Problem in Problem-based Learning is the Problems: But do they Motivate Students?, dalam Challenging Research into Problem-based Learning, SRHE and Open University Press Imprint General Editor: Heather Eggins, New York, hal. 22.

${ }^{36}$ Gwilym Wyn Roberts, Becoming a Problem-Based Learning Facilitator dalam Problem-Based Learning in Health and Social Care, editor: Teena J. Clouston et al, UK: Blackwell Publishing Ltd, 2010, hal. 54.
} 
Ahmad Zain Sarnoto, Nandang Burhanuddin

\section{Conclusion}

This study generally has the following conclusions: First, from the Qur'anic sign regarding the relationship between problem-based learning (PBL) concepts with counterradicalization content with various other branches of science, interconnected and interacted harmoniously and mutually perfecting each other. Thus, PBL in the counter-radicalism of the Qur'anic perspective carries theocentric eduhumanist theory. Where clearly, the Al-Qur'an prohibits radicalism, let alone carrying out acts of terror in any name, without justified reasons. Second, with the discovery of PBL principles in preventing radicalism from the perspective of the Al-Qur'an, this study can distinguish between various opinions on radicalism with several figures such as Shaykh Ahmad Thayyib, Shaykh 'Ali Jumu'ah, Sayyid Aqiel Siradj, Arsyad Mbai. Those who identify radicalism and acts of terror come from among Muslims who aspire to the establishment of Islam as dîn (religion), dunyâ (the institution of life) and daulah (the institution of a state).

This study also refers to the opinion of Imâm Ali Karramahullâhu Wajhah, Imâm AsySyâfi'i, Imâm Asy-Syâthibi, Shaykh Mahmûd Syaltût, Shaykh Y -suf Al-Qaradhâwi, Shaykh Wahbah Az-Zuhaily, and others who affirm the strength of Islam rahmatan lil '. Naturally, both in terms of concepts, morals, and strategies of struggle for i'lâllâh.

\section{References}

Adzh-Zhariry, Khâlid bin Shâlih bin Nahîdh, Daur At-Tarbiyyah fî Muwâjahat Al-Irhâb, Saudi Arabia: Kementrian Pendidikan Tinggi Universitas Ummul Qura, 1421 H.

Ahmad, Yûsuf Maqâshid Asy-Syarî’ah 'Inda Imâm Ibn Taymiyyah, Jordania: Dâr An-Nafâis, 2000.

Ahmed ,Akbar S., Islam sebagai Tertuduh, Bandung : Arasy Mizan, 2004.

Alim, N., Pairin, dkk, Singularitas Agama: Identifikasi Aliran dan Paham Radikal di Kendari, Al-Ulum, Volume 18 No. 2 (2 December 2018). 271-300.

Ar-Ruwasyid, Asmâ' binti Râsyid, Al-Qudwah, Dâr Al-Wathan Li An-Nasyr, 2010.

Astuti, “Diskursus Tentang Pluralitas Penafsiran Al-Qur'an,” Jurnal Hermeunetik Vol. 8, No. 1 (Juni 2014).

Ath-Thabari , Imâm, Jami' Al-Bayân fì Ta'wîl Al-Quran, Kairo: Hajar Li Ath- Thabâ'ah wa An-Nasyr wa At-Tauzi' wa Al-I'lân, tt, Cet. 2, Vol. 18.

Depdiknas, Kurikulum 2004; Mata Pelajaran Pendidikan Agama Islam Sekolah Menengah Atas dan Madrasah Aliyah, Jakarta: Depdiknas, 2003.

14 | IQ (Ilmu Al-qur'an): Jurnal Pendidikan Islam| Volume 4 No.01 2021, 1-16 
Ghufron, M. Nur \& Risnawita, Rini, “Teori Vygotsky dan Implikasinya dalam Pendidikan Agama Islam pada Anak”, Jurnal Elementary, , Vol.1 No.1 (Juli- Desember 2013).

Ibnu 'Âsyûr, Syaikh Muhammad Thâhir, Maqâshid Asy-Syarî'ah, Cet I. Jordania: IIIT, 1999.

Ismail, Noor Huda, Jihad Selfie Dying For Significance, Jakarta: Noura Books, 2018.

Maarif, Ahmad Syafii, Mencari Autentisitas di Tengah Kegalauan, Jakarta, PSAP, 2004.

Mauffette, Y., Kandlbinder, P., and Soucisse, A., "The Problem in Problem-based Learning is the Problems: But do they Motivate Students?", dalam Challenging Research into Problem-based Learning, Editor: Heather Eggins, New York: SRHE and Open University Press Imprint General, 2010.

Monks, F.J., AMP Knoers, \& Siti Rahayu Hadinoto, Psikologi Perkembangan, Pengantar dalam Berbagai Bagiannya, Yogyakarta : University Gadjah Mada Press, 2006.

Muqoyyidin, Andik Wahyun, "Membangun Kesadaran Inklusifmultikultural untuk Deradikalisasi Pendidikan Islam," dalam Jurnal Pendidikan Islam, Vol. I, No. 2, (Desember 2012).

Naharong, Abdul Muis Naharong, "Terorisme Atas Nama Agama,” Journal of Refleksi, , Vol. 13, No. 5. (2013)

Nurbaiti, "Pendidikan Humanistik Islami melalui Pembelajaran Aplikatif(Studi di Pondok Pesantren Darunnajah Ulujami, Jakarta”, Jurnal KORDINAT, Vol.XVIII No, 1, (April 2019)

Nisa', Khoirul Mudawinun, Reinterpretasi Jihad Pdm \& Pcnu Kota Madiun Sebagai Upaya Membendung Laju Radikalisme, Jurnal Piwulang, Vol. I No.8 (September 2018). 3353.

Pambayun, Ellys Lestari, Pendekatan Komunikasi Instruksional Pada Dosen Pendidikan Kewarganegaraan di Perguruan Tinggi, Jurnal Ilmu dan Budaya, , Vol. 37 No. 32. (2013). 3214.

--------, One Stop Qualitative Reserach Methodology in Communication, Jakarta: Lentera Cendekia, 2013.

Roberts, Gwilym Wyn, “Becoming a Problem-Based Learning Facilitator” dalam ProblemBased Learning in Health and Social Care, editor: Teena J. Clouston et al, UK: Blackwell Publishing Ltd, 2010.

Rokhmad, Abu, "Radikalisme Islam Dan Upaya Deradikalisasi Paham Radikal," dalam Jurnal Walisongo, Vol. 20, No. 1 (Mei 2012). 
Ahmad Zain Sarnoto, Nandang Burhanuddin

Setyanto, Arif “Opini Publik terhadap Terorisme di Eropa: Blind Spot Dalam Kasus Se rangan Norwegia Tahun 2011," dalam Jurnal Hubungan Internasional, , Vol. VI, No. 1 (2013).

Shihab, M. Quraish, Wawasan Al-Qur"an: Tafsir Maudhû" $i$ atas Pelbagai Persoalan Umat, Bandung: Mizan, 1996.

Shoubâni, Shâlih dkk, Qiyam At-Tasâmuh fii Al-Manâhij Al-Madrasiyyah Al- 'Arabiyyah, SA: Ramallah Centre for Human Rights Studies, 2012.

Tafsîr, Ahmad, Ilmu Pendidikan dalam Perspektif Islam, Cet. 9. Bandung: PT. Remaja Rosda Karya, 2010.

'Umar, Ahmad Rizky Mardhâtillâh, "Melacak Akar Radikalisme Islam di Indonesia,” dalam Jurnal Ilmu Sosial dan Ilmu Politik, Vol. 14, No. 2 (November 2010).

Yusup, Pawit, Komunikasi Instruksional, Bandung : Remaja Rosdakarya, 2010.

\section{Internet Sources}

https://www.tempo.co/abc/4505/radikalisme-berbalut-pendidikan-sudah-menyasar-anak-usiadini-di-indonesia

https://www.google.co.id/?AzyumardiAzra.Rekrutmen/Anak/Sekolah. diakses tanggal 05-042017 